DOI: https://doi.org/10.36910/6775-2524-0560-2020-41-11

УДК: 004.056: 004.3

Ліщина Наталія Миколаївна, к.т.н., доцент

https://orcid.org/0000-0002-5200-536X

Ліщина Валерій Олександрович, к.т.н., доцент

https://orcid.org/0000-0002-2371-3850

Матвіїв Юрій Ярославович, д.т.н., професор

https://orcid.org/0000-0002-2236-2200

Ящук Андрій Анатолійович, к.т.н.

https://orcid.org/0000-0003-4872-7949

Луцький національний технічний університет

\title{
АНАЛІЗ МЕТОДІВ ВИЗНАЧЕННЯ РИЗИКІВ ТА УПРАВЛІННЯ НИМИ ПРИ РОЗРОБЦІ ПРОГРАМНОГО ЗАБЕЗПЕЧЕННЯ
}

\begin{abstract}
Ліщина Н.М., Ліщина В.О., Матвіїв Ю.Я., Ящук А.А. Аналіз методів визначення ризиків та управління ними при розробці програмного забезпечення. В рамках дослідження розглянуто особливості управління ризиками проєктів в IT сфері. Висвітлені основні методи визначення ризиків та підходи до їх подолання. Описано процес ідентифікації зон ризику, який може вплинути на успіх проєкту. Пояснено процес управління ризиками для IT-проєктів, що зможе допомогти команді проєкту мінімізувати потенційні ризики та максимізувати потенційні можливості.
\end{abstract}

Ключові слова: ІТ-проєкт, управління ризиками, прогнозування ризиків, управління проєктами.

Лищина Н.М., Лищина В.А., Матвиив Ю.Я., Ящук А.А. Анализ методов определения рисков и управление ими при разработке программного обеспечения. В рамках исследования рассмотрены особенности управления рисками проектов в ІТ сфере. Освещены основные методы определение рисков и подходы к их преодолению. Описан процесс идентификации зон риска, который может повлиять на успех проекта. Объяснено процесс управления рисками для ITпроектов, который сможет помочь команде проекта минимизировать потенциальные риски и максимизировать потенциальные возможности.

Ключевые слова: IT-проект, управление рисками, прогнозирования рисков, управление проектами.

Nataliia Lishchyna, Valeriy Lishchyna, Matviiv Yurii, Yashchuk Andrii. Analysis of methods for identifying risks and managing them in software development. The study examines the features of risk management of projects in the IT field. The main methods of risk identification and approaches to overcoming them are highlighted. Describes the process of identifying risk areas that may affect the success of the project, explains the process of risk management for IT projects, which can help the project team to minimize potential risks and maximize potential opportunities.

Keywords: IT project, risk management, risk forecasting, project management.

\section{Постановка проблеми.}

Розробка програмного забезпечення - це діяльність, яка використовує різноманітні технологічні досягнення і вимагає високого рівня знань. Через ці та інші фактори кожен проєкт 3 розробки програмного забезпечення містить елементи невизначеності. Це поняття відоме як проєктний ризик. Успіх проєкту з розробки програмного забезпечення в значній мірі залежить від рівня ризику, який відповідає кожному виду діяльності. Керівнику проєкту, недостатньо лише усвідомлювати ризики. Для досягнення успішного результату керівництво проєктом повинно визначити, оцінити, визначити пріоритети та управляти усіма основними ризиками [4].

Усі проєкти розробки програмного забезпечення та будь які інженерні роботи із створення програмного забезпечення різняться завдяки новим функціям, більшій ефективності або використанню досягнень у галузі програмної інженерії. Будь-який керівник програмного проєкту погодиться з тим, що досягнення таких можливостей не може рухатися вперед без ризику[4].

Оскільки ризики дійсно реальні і досить поширені у всіх програмних проєктах, вкрай необхідно, щоб зацікавлені сторони наполегливо працювали над виявленням, розумінням та пом'якшенням будь-яких ризиків, які можуть загрожувати успіху проєкту. Що стосується проєктів, які мають обмеження у часі та витратах. Досвід часто показує, що успішними проєктами з розробки програмного забезпечення є ті, у яких зменшення ризику є основною діяльністю управління.

Що таке ризик у розробці програмного забезпечення? Насправді, ризик є потенційною проблемою. Це діяльність або подія, яка може скомпрометувати успіх проєкту з розробки програмного забезпечення. Ризик - це ймовірність зазнати збитків, а загальний ризик для конкретного проєкту буде враховувати як імовірність, так і розмір потенційної втрати. «Гарантування необхідного рівня якості програмного забезпечення - це процес, який функціонує паралельно розробці програмного забезпечення. Основна увага приділяється вдосконаленню процесу розробки програмного забезпечення для запобігання ризиків до того, як вони стануть головною проблемою» (Сіваковська, 2020, с. 67).

○ Ліщина Н.М., Ліщина В.О., Матвіїв Ю.Я., Ящук А.А 


\section{Формування мети дослідження.}

Метою дослідження є аналіз методів та механізмів управління ризиками проєктів IT-галузі, аналіз зон ризику, які можуть вплинути на успіх проєкту. Пояснити процес управління ризиками для IT-проєктів, як такий, що зможе допомогти команді проєкту мінімізувати потенційні ризики.

\section{Виклад основного матеріалу.}

Припущення та антикризове управління не забезпечують повну ефективність проєкту. Виявлення та управління ризиками є єдиним прогнозуючим методом для виявлення ймовірності того, що проєкт розробки програмного забезпечення зазнає незапланованих або неприпустимих подій. Сюди входять припинення, розриви, затримки графіків, заниження вартості та перевитрата ресурсів проєкту

Що таке управління ризиками в програмній інженерії? Управління ризиками означає стримування та пом'якшення ризиків. По-перше, потрібно визначити та спланувати. Потрібно діяти, коли виникає ризик, спираючись на досвід та знання всієї команди, щоб мінімізувати вплив на проєкт.

Управління ризиками включає такі завдання:

- визначити ризики та їхні причини;

- класифікувати та визначити пріоритети всіх ризиків;

- скласти план, який пов'язує кожен ризик із пом'якшенням наслідків;

- відстежити напрями ризику під час проєкту;

- застосувати пом’якшувальні дії, якщо будь-який ризик матеріалізується;

- повідомити про стан ризику протягом проєкту;

- визначити та класифікувати ризики.

Більшість проєктів програмної інженерії за своєю суттю $є$ ризикованими через різні потенційні проблеми, які можуть виникнути. Досвід інших проєктів програмної інженерії може допомогти менеджерам класифікувати ризик. Тут важливо не діапазон класифікації, а точне визначення та опис усіх реальних загроз успіху проєкту. Проста, але ефективна схема класифікації полягає у впорядкуванні ризиків за сферами впливу.

Для більшості проєктів з розробки програмного забезпечення ми можемо визначити п'ять основних сфер впливу на ризик:

- нові, неперевірені технології;

- користувацькі та функціональні вимоги;

- архітектура додатків та систем;

- продуктивність;

- організаційні вимоги.

Нові, неперевірені технології. Більшість програмних проєктів передбачають використання нових технологій. Постійно мінливі інструменти, методи, протоколи, стандарти та системи розробки збільшують ймовірність того, що технологічні ризики виникнуть практично за будь-яких значних зусиль, спрямованих на розробку програмного забезпечення. Навчання та знання мають надзвичайно важливе значення, i неправильне використання нових технологій найчастіше призводить безпосередньо до провалу проєкту.

Користувацькі та функціональні вимоги. Вимоги до програмного забезпечення враховують усі потреби користувачів щодо функцій, функцій та якості обслуговування програмної системи. Дуже часто процес визначення вимог $є$ тривалим, нудним і складним. Більше того, вимоги, як правило, змінюються з відкриттям, прототипуванням та інтеграцією. Зміна елементарних вимог, швидше за все, поширюватиметься протягом усього проєкту, а модифікації вимог користувача можуть не перетворитися на функціональні вимоги. Ці збої часто призводять до однієї або декількох критичних помилок погано спланованого проєкту з розробки програмного забезпечення.

Архітектура додатків та систем. Неправильний напрямок з платформою, компонентом або архітектурою може мати катастрофічні наслідки. Як і у випадку з технологічними ризиками, життєво важливо, щоб команда включала експертів, які розуміють архітектуру та здатні робити обгрунтований вибір дизайну.

Продуктивність. Важливо переконатись, що будь-який план управління ризиками охоплює очікування користувачів та партнерів щодо ефективності. Потрібно враховувати контрольні показники та порогові випробування протягом усього проєкту, щоб забезпечити рух робочих продуктів у правильному напрямку.

Організаційні вимоги. Організаційні проблеми можуть мати несприятливий вплив на результати проєкту. Керівництво проєктом повинно планувати ефективне виконання проєкту та (О) Ліщина Н.М., Ліщина В.О., Матвіїв Ю.Я., Ящук А.А 
знаходити баланс між потребами команди розробників та очікуваннями замовників. Звичайно, адекватний підбір персоналу включає вибір членів команди 3 наборами навичок, які добре відповідають проєкту.

На самому верхньому рівні можна виділити три основні групи ризиків:

- $\quad$ ризик проектування;

- $\quad$ технічний ризик;

- $\quad$ бізнес-ризик (діловий ризик).

Ризики проектування включають ризики, пов'язані з невизначеністю у фінансуванні проєкту, в кваліфікації персоналу, мінливість вимог замовника, несвоєчасними поставками технічних $\mathrm{i}$ програмних засобів і так далі. Крім того, факторами ризику є складність і розмір програмного вироби.

Технічний ризик з'являється в результаті того, що розробник на перших етапах не може передбачити всіх складнощів, які проявляться на етапах розробки, тобто проблема завжди складніше, ніж вона оцінюється спочатку.

Найбільш підступний - діловий ризик. Наприклад, створений прекрасний продукт, який ще не відповідає вимогам ринку, або створений продукт не відповідає стратегічній лінії компанії, або припинено бюджетне фінансування і тому подібні.

Можна запропонувати також наступну категоризацію ризиків:

- ризики пов'язані з вимогами;

- $\quad$ технологічні ризики;

- ризики пов'язані з кваліфікацією персоналу;

- $\quad$ політичні ризики.

РМВОК рекомендує керувати ризиками у 4 етапи:

1. Ідентифікація. Виявити ризики, котрі можуть перешкодити цілі проєкту. На практиці, зазвичай, технічні ризики у IT-проєкті з'являються дуже часто, та їх простіше вирішити. Більш складніше вирішувати такі ризики, як «політичні ігри», «небажання, опір підрядників, користувачів», «відсутність підтримки керівництва», «недостатнє фінансування».

2. Аналіз. Завдання цього етапу полягає в визначенні найнебезпечніших із ідентифікованих ризиків, тому що боротьба із всіма ризиками водночас неефективна і дорога.

3. Планування. На цьому етапі саме відбувається управління проєктами. Для кожного ризику зі списку критичних потрібно розробити стратегію боротьби із ним. Усього використовують три стратегії:

Transfer. Перекладаємо відповідальність за наслідки ризику на третю сторону (замовника, страхову компанію, партнера та ін.). Застосовувати цю стратегію завжди є зміст, якщо самі не можемо вплинути на ризик та $є$ на кого цю відповідальність перенести.

Accept. Приймаємо ми відповідальність за наслідки ризику на себе, та нічого не робимо, залишаємо усе як $є$. Використовувати цей підхід $\epsilon$ зміст тільки коли із ризиком вдіяти ми нічого не можемо, а робити трансфер на іншу сторону невиправдано дорого.

Mitigate. Боремося із ризиком, при цьому беручи відповідальність за нього на себе. Задля боротьби із ризиком добре мати декілька планів: основний, для того, щоби ризик подавити, та відхідний, на випадок коли ризик усе ж таки трапився та впливає на проєкт.

4. Моніторинг та контроль. Піддержувати план проєкту та перелік ризиків у актуальному стані. Використовують на практиці статистичні методи прогнозування ризиків [1].

Ризики відрізняються від проблем і труднощів, так як вони мають відношення до майбутніх, потенційно можливих негативних результатів і збитків. Оцінюється ймовірність за ступенем визначеності, із якою можливо прогнозувати прояв кожного ризику у проєкті, який полягає у переростанні даного ризику у проблеми для проєкту. SEI (Software Engineering Institute) радить використовувати три методики управління ризиком проєктів:

1) SRE (Software Risk Evaluation) методологія оцінювання ризику містить формальний метод ідентифікації, контролю, аналізу та усунення ризиків проєктів, що застосовується спочатку на ранній стадії розробки ПС (до укладення договору із розробником та потім періодично у ході усього життєвого циклу проєкту.

2) Методологія безперервного керування ризиком CRM (від Continuous Risk Management) основана на деяких принципах управління ризиком у ході всього ЖЦ проєкту та не залежить від конкретних застосовуваних методів і інструментів оцінки і усунення ризиків. 
3) Методологія колективного управління ризиком TRM (від Team Risk Management) описує додаткові дії у діяльності із управління ризиком, котрі пов'язані з здійсненням колективного управління ризиком зі сторони замовника проєкту і його виконавця [1].

Організація робіт із аналізу ризиків виконується в наступній послідовності:

1) підбір команди експертів;

2) підготовка запитань та зустрічі з експертами;

3) вибір техніки аналізу ризику;

4) установлення факторів ризику і їх значимості;

5) розробка моделі механізму дії ризиків;

6) встановлення зв'язків між окремими ризиками та сукупного ефекту від їх дії;

7) розподіл ризиків між учасниками проєкту;

8) перегляд результатів аналізу ризиків, найчастіше у вигляді звіту [2].

Ризики можуть стати проблемами, якщо ними ефективно не управляти. В рамках MSF (Microsoft Solutions Framework) управління ризиками розглядається як процес їх виявлення, аналізу та ефективної превентивної роботи над ними. Ефективний процес виявлення і управління ризиками допомагає досягти розумних компромісів між згаданими небезпеками i можливостями, що відкриваються.

У процесі виявлення ризиків проектна група намагається чітко сформулювати і перерахувати всі наявні в проєкті ризики. На початковій стадії проєкту може бути організований семінар або мозковий штурм з метою виявлення ризиків, що виникають в нових умовах. Як мінімум, в результаті процесу виявлення ризиків повинні бути отримані їх чіткі, однозначні й узгоджені формулювання, представлені у вигляді списку ризиків.

Після того як ризики ідентифіковані, їх треба проаналізувати. Огляд математичних моделей і методів, які використовуються при аналізі ризиків, наведено в табл. 1.

Таблиця 1 - Характеристика найпоширеніших методів аналізу ризиків

\begin{tabular}{|c|c|c|}
\hline $\begin{array}{l}\text { Вид методів } \\
\text { аналізу }\end{array}$ & Метод & Характеристика методу \\
\hline \multirow[t]{5}{*}{ Якісні } & $\begin{array}{l}\text { Ймовірнісний } \\
\text { аналіз }\end{array}$ & $\begin{array}{llcr}\text { Ймовірність виникнення } & \text { втрат визначається на } & \text { основі } \\
\text { статистичних } & \text { даних, які передували ризикованому } \\
\text { достатності інвестицій, коефіцієнта ризику } & & \end{array}$ \\
\hline & Експертний аналіз & $\begin{array}{l}\text { Метод використовується в разі відсутності чи недостатнього } \\
\text { обсягу початкової інформації та полягає у залученні експертів для } \\
\text { оцінки ризиків }\end{array}$ \\
\hline & Метод аналогів & $\begin{array}{l}\text { Користування базою даних по здійснених аналогічних проєктах } \\
\text { задля перенесення їх результативності на проєкт, що } \\
\text { розробляється }\end{array}$ \\
\hline & $\begin{array}{l}\text { Аналіз сценаріїв } \\
\text { розвитку проєкту }\end{array}$ & $\begin{array}{l}\text { Цей метод передбачає розробку декількох варіантів розвитку } \\
\text { проєкту та їх порівняльну оцінку. Розраховується самий } \\
\text { песимістичний варіант можливої зміни змінних, самий } \\
\text { оптимістичний та найбільш вірогідний варіант }\end{array}$ \\
\hline & $\begin{array}{l}\text { Метод побудови } \\
\text { «дерева рішень» }\end{array}$ & $\begin{array}{l}\text { Передбачає покрокове розгалуження процесу реалізації проєкту з } \\
\text { оцінкою витрат, збитків і вигод }\end{array}$ \\
\hline \multirow[t]{3}{*}{ Кількісні } & $\begin{array}{l}\text { Аналіз показників } \\
\text { граничного рівня }\end{array}$ & $\begin{array}{l}\text { Визначення ступеня стійкості проєкту по відношенню до } \\
\text { можливих змін умов його реалізації }\end{array}$ \\
\hline & $\begin{array}{l}\text { Аналіз чутливості } \\
\text { проєкту }\end{array}$ & $\begin{array}{l}\text { Цей метод дозволяє оцінити, як саме змінюються результуючі } \\
\text { показники реалізації проєкту при різних даних змінних, } \\
\text { необхідних для розрахунку }\end{array}$ \\
\hline & Імітаційні методи & $\begin{array}{l}\text { Ці методи базуються на покроковому знаходженні значення } \\
\text { результуючого показника за рахунок проведення багатократних } \\
\text { дослідів } 3 \text { моделлю }\end{array}$ \\
\hline
\end{tabular}

Після каталогізації всіх ризиків за типами, керівник проєкту з розробки програмного забезпечення повинен розробити план управління ризиками. Як частина більш широкого, всебічного плану проєкту, план управління ризиками окреслює реакцію, яка буде прийнята щодо кожного ризику - якщо він реалізується [3]. 
На даному етапі має бути вироблений план боротьби із ризиками в IT-проєкті на основі оцінювання ймовірностей і вироблена стратегія попередження.

Не потрібно розробляти безліч антиризикових заходів на кожний можливий та неможливий ризик у проєкті. Інакше можливо отримати великий перелік робіт за проєктом, що збільшує терміни його виконання як мінімум в 2 рази. Це відвертає увагу від основної мети проєкту, зосереджуючи ресурси на запобіганні можливих негативних наслідків.

Отож, при оцінці ризиків та розробці заходів щодо їх запобігання важливий принцип Парето 80/20. Тому, при розробці антиризикових заходів треба вибрати ті $20 \%$ ризиків, які на $80 \%$ впливають на успіх чи провал проєкту, а для цих ризиків спланувати антиризикові заходи. При цьому зі всього переліку заходів треба знову таки вибрати тільки 20\%, котрі запобігають $80 \%$ ризиків [3].

Щоб бути ефективним, моніторинг програмного ризику повинен бути невід'ємною частиною більшості проєктів. По суті, це означає часті перевірки під час зустрічей проєкту та критичних подій. Моніторинг включає: публікування звітів про стан проєкту та питання управління ризиками; перегляд планів ризиків відповідно до будь-яких серйозних змін у графіку проєкту;перегляд та перевірка пріоритетів ризиків, усуваючи ризики 3 найменшою ймовірністю; мозковий штурм щодо потенційно нових ризиків після змін у графіку або масштабі проєкту. Коли виникає ризик, відповідну реакцію щодо пом'якшення слід взяти із плану управління ризиками.

Таблиця 2 - Дії команди проєкту по попередженню ризиків

\begin{tabular}{|l|l|}
\hline Дії & Перелік питань до вирішення \\
\hline $\begin{array}{l}\text { Дослідження } \\
\text { (research) }\end{array}$ & $\begin{array}{l}\text { Чи достатньо ми володіємо інформацією про даний конкретний ризик? Чи } \\
\text { ми повинні краще вивчити його, щоби отримати про нього більше } \\
\text { iнформації? }\end{array}$ \\
\hline Ухвалення (accept) & $\begin{array}{l}\text { Чи можемо пережити наслідки ризиків, якщо вони настануть? Чи можемо ми } \\
\text { прийняти ризики та не здійснювати з цього приводу ніяких подальших дій? }\end{array}$ \\
\hline Уникнення (avoid) & Чи можемо уникнути ми ризиків, змінивши спосіб дії? \\
\hline $\begin{array}{l}\text { Перенесення } \\
\text { (transfer) }\end{array}$ & $\begin{array}{l}\text { Чи можемо перенести ризик на деякий інший проєкт, проєктну групу, } \\
\text { організацію чи приватних осіб? }\end{array}$ \\
\hline $\begin{array}{l}\text { Запобігання } \\
\text { (mitigation) }\end{array}$ & $\begin{array}{l}\text { Чи можна щось зробити заздалегідь для зменшення ймовірності ризику чи } \\
\text { иого загрози? }\end{array}$ \\
\hline $\begin{array}{l}\text { Пом'якшення } \\
\text { наслідків } \\
\text { (contingency) }\end{array}$ & $\begin{array}{l}\text { Чи може бути загроза ризику зменшена шляхом планування певної реакції } \\
\text { на нього? }\end{array}$ \\
\hline
\end{tabular}

Протягом усього проєкту життєво важливо забезпечити ефективну комунікацію між усіма зацікавленими сторонами, менеджерами, розробниками, службою контролю, особливо маркетингом та представниками споживачів. Обмін інформацією та отримання відгуків про ризики значно збільшить ймовірність успіху проєкту.

\section{Висновки}

В статті охарактеризовано такі поняття, як управління програмними проєктами та ризиками їх реалізації, що дало змогу визначити компоненти такого управління, основні категорії ризиків, ризикорієнтовний підхід до процесу управління. 3'ясовано основні завдання процесу управління ризиками реалізації програмних проєктів, розроблено відповідні рекомендації, які дають змогу керівництву ITкомпанії передбачити появу негативних ситуацій i, як наслідок, подальших потенційних проблем, що вимагатиме від них попередньої підготовки персоналу до їхнього настання. Виявлено, що підготовка заходів реагування на потенційні проблеми зводиться до визначення певного набору дій, які потрібно зробити для того, щоб підсилити позитивні результати прояву ризикових подій і послабити негативні їх наслідки.

Список бібліографічного опису.

1. Андон Ф. И., Коваль Г. И., Коротун Т. М., Лаврищева Е. М., Суслов В. Ю. Основы инженерии качества программных систем. 2-е изд., перераб. и доп. К. Академпериодика, 2007. 672 с.

2. Галенко Н. І., Фісун М. Т. Моделі ризиків у проєктах зі створення програмного забезпечення. Наукові праці: Науково-методичний журнал. Т. 106. Вип. 93. Комп’ютерні технології. Миколаїв. Вид-во ЧДУ ім. П. Могили, 2009. c. $89-96$.

3. Дубровін В. І., Льовкін В. М. Прийняття рішень у процесі управління ризиками проєктів: навчальний посібник. Запоріжжя. ЗНТУ, 2012. 196 с.

4. Sandra M. N., Sandra M.N., Carlos S. da S. Eduardo Risk management applied to software development projects in incubated technology-based companies: literature review, classification, and analysis. Gest. Prod., São Carlos. 2016, №23(4). P. 798-814. 
5. Сіваковська О. М., Ліщина Н. М. Основні підходи до управління якістю програмного забезпечення. Збірник матеріалів міжнародної науково-практичної конференції "Die wichtigsten Vektoren für die Entwicklung der Wissenshaft im Jahr 2020”, 24 січня 2020 р. Люксембург: АОГОГ, 2020. С.67-68.

\section{References.}

1. Andon F. Y., Koval G. Y., Korotun T. M., Lavryshheva E. M., Suslov V. Yu. Osnovy ynzheneriyi kachestva programmnyx system. 2-e yzd., pererab. y dop. K. : Akademperyodyka, 2007. $672 \mathrm{s.}$

2. Galenko N. I., Fisun M. T. Modeli ryzykiv u proektax zi stvorennya programnogo zabezpechennya. Naukovi praci: Naukovometodychnyj zhurnal. T. 106. Vyp. 93. Kompyuterni texnologiyi. Mykolayiv. Vyd-vo ChDU im. P. Mogyly, 2009. s. 89-96.

3. Dubrovin V. I., Lovkin V. M. Pryjnyattya rishenu procesi upravlinnya ryzykamy proektiv: navchalnyj posibnyk. Zaporizhzhya : ZNTU, 2012. $196 \mathrm{~s}$.

4. Sandra M. N., Sandra M.N., Carlos S. da S. Eduardo Risk management applied to software development projects in incubated technology-based companies: literature review, classification, and analysis. Gest. Prod., São Carlos. 2016, №23(4). P. 798-814.

5. Sivakovska O. M., Lishchyna N. M. Osnovni pidkhody do upravlinnia yakistiu prohramnoho zabezpechennia. Zbirnyk materialiv mizhnarodnoi naukovo-praktychnoi konferentsii "Die wichtigsten Vektoren für die Entwicklung der Wissenshaft

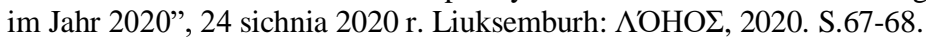

